\title{
Transfer Pricing System in Banks
}

\author{
Av. Ergys Misha
}

Lawyer; Email: ergys_2005@yahoo.it

Doi:10.5901/ajis.2015.v4n3s1p509

\section{Abstract}

In today's environment of banking services industry, where competition is emerging every day, where the customer's requirements are becoming sophisticated and the number and diversity of products and geographic markets is growing, maintaining margins is becoming more and more difficult. Developing a successful activity, profitable and sustainable has become one of the key factors to survive. Consequently, performance measurement systems take a special significance as the most important techniques in decision making processes. Currently, commercial banks operating in the Albanian banking market does not follow a specific model/method for assessing profitability and performance for each organizational unit. Generally banks, in the process of measuring their performance, are guided by budgeting process detailed of each unit within the bank and fulfillment of the objectives set. But, these objectives refer only to level of sales (eg., collected deposits or loans granted) for each unit/branch and don't distribute costs generated by each cost centers. Funds transfer pricing is a technique suggested to assist banks in measuring profitability. This technique allows managers to compare the profitability of different products, different branches and management and economic performance of the various units. This paper discusses the key principles of functioning of a transfer pricing system, and actually it as a useful method to be used in measuring the performance of various units within a bank. First, the paper briefly addressed the cost of funds for banks, as a starting point for setting the transfer price. Then it treats methodologies for determining the transfer price. Finally, at the end it addressed the application of the system of internal transfer price in a hypothetical example which derives into specific conclusions.

Keywords: transfer pricing system; cost of funds for banks; marginal cost and average cos; single - pool method; multiple - pool method.

\section{Chapter 1}

\subsection{What is a transfer pricing system?}

Transfer pricing system is the allocation of net interest income in different organizational units of the bank. For example, if one unit of the bank has a lack of funds, what is the rate that it should apply in the funds received by other units of the bank to enable the financing of loans or investments? And if one unit of the bank has surplus funds, how much should it benefit from the funds it provide toward the unit that has lack of funds?

So, the transfer pricing system is an internal accounting system or an accounting tool that transfer price from one division of a company (business unit that generate assets (loans/ investments) to another division of the same company (business unit that provide funding) for a product transferred between the two divisions.

In the absence of the transfer pricing system of funds, end users of funds will receive loan for the interest income without paying for the full amount of interest expenses, while the final providers of funds will pay for interest expenses without credited for the total amount of interest income. In such environment, users of funds have the advantage because of all interest income are related to assets and interest expenses are related to liabilities. This makes the user's funds look profitable compare to funding providers. From the perspective of the bank as a whole, this situation does not create any problem because interest expenses and interest income are analyzed in total.

However, bank management should know where and how the profit is generated into the bank, in the product level, unit or client. For this purpose, it is suggested the use of transfer pricing system. Transfer pricing provides a domestic source of revenue for the providers of funds and a domestic interest expense for users of funds.

Finally, it should be noted that the transfer pricing system is part of the control system and management accounting, which includes budgeting, planning, profit and asset-liability management. All these systems must be guided by a single philosophy to achieve the coordination of the efforts of the organization towards the objectives 


\section{Chapter 2}

\subsection{Average and marginal cost of funds}

As mentioned above, the transfer pricing system is a process of interest income attribution to internal business units on various levels. As a result, during the implementation of this system it is necessary for banks to recognize their cost of funds. For this reason it is important to treat the method of calculating the cost of funds by the bank. Below is treated the average and marginal cost of funds.

The average cost of funds is a measure of average interest rate that banks and other financial institutions pay to use their funds that may be customer's deposit/money, equity, borrowed funds, etc. The average interest cost for the entire portfolio is calculated by taking the total interest expense on annualized basis and dividing that total by the average interest bearing deposits and other interest-bearing borrowings. And for each source of funds, is calculated as ratio of interest expenses by source to the average outstanding debt for that source.

The primary problem with the historical cost is that it does not generally reflect current market valuation and consequently does not provide any information for interest rate changes (increase or decrease of future interest rate). The use of average costs assumes that interest rates will remain constant at historical levels during the current pricing period.

Average historical cost can be used very well is evaluating the past performance. It is relatively easy to understand, after the fact, why a bank's expenses and profits differ from those of peer banks by comparing average borrowing costs and assets yield. Average costs of non-interest expenses (commissions, etc.) can be evaluated and applied in the calculation of total costs of providing additional funds.

The marginal cost of funds represents the incremental cost of obtaining financing. For its calculation should include interest and non-interest expenses, and to determine which part of the funds will be invested according to the types of assets. An approximate formula for calculating the marginal cost of funds from a single source, when all related costs are known, is given below:

Interes rate + servicing costs + acquisition costs + insurance

Marginal cost $=$ $1-\%$ of funds in non earning assets

Denominator includes the liabilities that will be invested to generate income (the rest is related to the creation of reserves, or keeping balances on hand and current accounts of correspondents). All elements of the nominator represent the expected costs for each additional unit of funds, returned on an annual basis. A bank may also add indirect costs to the numerator, such as the implicit cost of increased risk associated with higher leverage, to obtain an effective marginal cost estimate. From all of the above mentioned costs, only acquisition costs are determined by the volume of check processing business handled by a bank.

\subsection{Marginal cost vs Average cost}

When interest rates rise, the marginal costs exceed historical/average cost. The reverse is true when interest rates fall. Marginal costs also serve as an indicator of the relative costs of different sources of funding. This helps the bank to choose the source with the least expensive source for financing growth.

\subsection{Weighted marginal costs}

The cost of debt. The marginal cost of different types of debt varies according to the magnitudes of each type of liabilities. High volume transactions accounts generate substantial servicing costs and have the highest reserve requirements and floats. The advantage of low interest is offset by other costs and the fact that the banks can invest only a smaller percentage of investable funds. Purchased funds, in contrast, pay higher rates by carry smaller transactions costs and require lower reserves with greater investable balances.

The cost of equity. The cost of capital refers to the expected returns of shareholder and differ only in their perspectives (shareholders versus company). There are several methods used for determining cost of capital or this required return such as dividend valuation model, CAPM (Capital Asset Pricing Model), etc.

Weighted marginal cost of total funds. Many banks price loans using the marginal cost of a single source of debt funds as the base rate (example: LIBOR, Treasury Bills, etc.). Unfortunately the cost of any single source of funds may change more or less than the cost of other sources and thus vary substantially from the bank's composite cost of 
financing.

So the weighted marginal cost of total funds, which averages the required returns from all long-term financing sources (Debt and Equity), is the best cost measure for pricing the assets. It is the opportunity cost of not investing existing funds elsewhere. This measure includes all costs (implicit and explicit) associated with each source of funds.

Weighted marginal cost of total funds is estimated in three stages:

1. Estimate the necessary amount of funding to be provided by any source of funds (debt and equity) over a certain time horizon and identify the most important changes in the composition of liabilities during this horizon.

2. Assess the marginal cost of each source of funds (the forecast of direct costs - interest and dividends allocation of indirect costs and calculation of the part that will invest in nonearning assets). Here we must keep in mind the fact that the debt leverage ratio could bring change to the bank's risk level, and this will have an impact on interest rates demanded by investors.

3. The management of the bank should combine individual assessments for calculating the weighted cost, which is the arithmetic average (mean) capital cost, where the contribution of each capital source is weighted by the proportion of total funding it provides.

Unfortunately it is very difficult to accurately measure the marginal cost. There are two problems that can lead to large errors during the measurement:

1. Relevant interest rate should be predicted to all investment time horizons and this is a very difficult task at a time when interest rates are very unstable. So the projections need to be modified whenever interest rates change.

2. It is difficult to determine exactly what proportion of total expenditure, staff costs and other indirect costs shall be allocated to each single source of funds. On the other hand, a part of these costs are fixed and do not change when additional funds are provided.

The evaluation of marginal cost is not exact. However useful decisions can be made but as long as the data are reported and analyzed in a consistent manner.

\section{Chapter 3}

\subsection{Internal Pricing System and Marginal Cost}

Most large banks are divided into organizational units with well-defined sets of responsibilities. Considered separately, each unit typically attracts source of funds and also uses funds directly. Banks establish internal funds transfer systems to allocate funds between units. Under such systems, a unit that is a user of funds pays an interest charge for the funds, while a supplier of funds receives credit. Marginal cost of funds estimates determine the return to suppliers of funds and the cost of funds users. Because each unit is viewed as a separate profit center, these cost estimates are extremely important.

The application of the transfer pricing system in the bank provides the following advantages:

- Correctly identify the cost of oppotunity value of funds.

- Enhance asset and liability pricing decisions.

- Separate credit risk from interest rate risk.

- Facilitate the profitability measurement of various products and components.

In the best funds transfer system, each organizational unit or profit center is assigned specific bank assets and liabilities, which it generates through normal business activity. It then separately sells its liabilities to a funds management profit center and buys financing for its assets from the funds management units at appropriate transfer prices, which serve to cover their operational costs/expenses. The funds management unit sets each transfer price, which varies depending on the characteristics of the underlying instruments.

One of the main dilemmas of banks in this process is whether to use multiple source systems or a single source system.

\subsection{Transfer Pricing Methodologies.}

There are three methods in determining the efficient transfer pricing system within an organization. Method of a single source is the simplest method and simultaneously less effective. Method of multiple sources is a good method because it 
better reflects market movements. More complex and effective methods is the method of compliance of maturities mismatches.

The method of a single source of funding (single - pool). According to this method, all funds are allocated to the same pool and one rate is quoted to all users. While the single - pool system is easy to understand and use it does not assist in handling interest rate risk or separating interest rate risk from credit risk.

The method of multiple sources (multiple - pool). Funds management group faces with variety sources of funds and each of them has its marginal cost and various maturities and thus different interest rate risk. They reflect the composition of bank liabilities according to types of financing source and re-pricing frequency. Therefore in this method these source of fund are used more than one cost of funds rate. Number of rates that will be used will be influenced by the re-pricing characteristics of sources and uses of funds. The advantage of this method is that it is more realistic. However, it is a complex method.

One of the main dilemmas of banks in this process is whether to use multiple source systems or a single source system. Multiple option may seem desirable at first glance, but its use can cause adverse effects during the transfer price calculation. The most serious consequences are:

$>$ Wrong allocation of resources.

> Margin that are calculated in different ways and cannot be compared between different products.

$>$ Inaccurate measurement of overall interest risk for the institution.

$>$ Incorrect conclusions regarding credit risk and interest rate.

If transfer pricing methodology is correct, the interest rate risk will be isolated from the operating units, which do not have any control over interest rate. The fund management center, which usually is a unit within the Treasury Department, will treat/manage this risk. In this way it is possible to measure the actual performance of the business units in a more accurate and more productive way.

If the transfer pricing system is properly implemented, the bank can determine the contribution of loans, deposits and interest rate on net interest margin.

\subsection{Example of a sample funds allocation scheme.}

In this example, there are three profit centers: lending, investment and deposit gathering. Each box represents a separate profit center.

The funds management unit is a forth profit center, responsible for borrowing in the money and capital markets. Each profit center generates revenews and expenses associated with transfer prices as well as with normal business activities.

The lending and investment centers compare transfer prices plus actual operating costs with revenues obtained directly from assets booked by each unit. The net difference determines the division profit. The deposit gathering unit receives a credit for suppying funds, which it compares to its actual acquisition and processing costs. The funds management unit makes a profit if the transfer prices it charges on financing loans and investments exceed the sum of the transfer prices it pays for deposits and its actual borrowing and personnel costs.

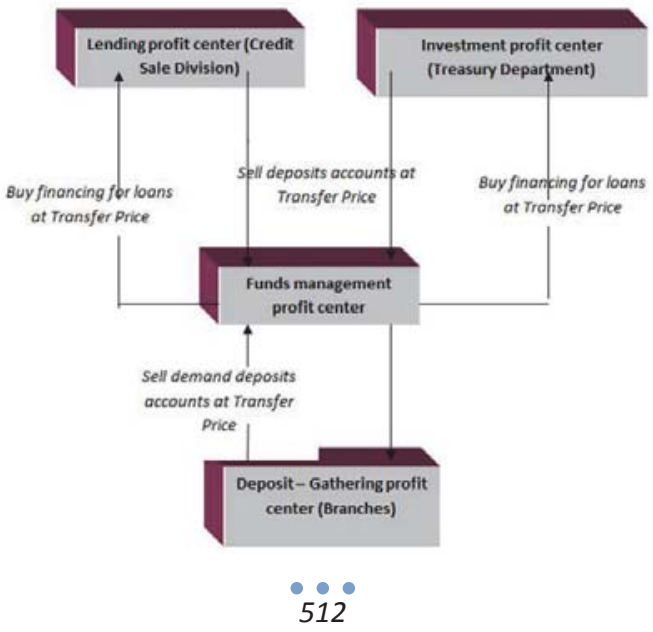




\title{
Profit Center 1 - Lending Profit Center
}

Net Income $=$ Loan Yields + Transfer Prices on Deposits Generated - Transfer Prices on Loan Financing - Actual Cost of Making Loans

\section{Profit Center 2 - Investments Profit Center \\ Net Income $=$ Security Yields + Transfer Prices on Deposits - Transfer Prices on Security Financing -} Actual Cost of Investing

\author{
Profit Center 3 - Deposit-Gathering Center \\ Net Income $=$ Transfer Prices on selling Demand Deposit Accounts - Actual Personnel and Handling \\ Costs
}

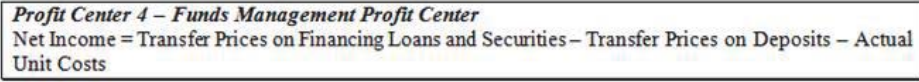

Funds transfer pricing scheme may employ a weighted average marginal cost of funds allocation or a single-source marginal cost allocation. If the funds management unit uses a fully weighted cost system, it sets the transfer price equal to the weighted marginal cost of capital.

The principal advantage of internal funds transfer pricing is that it separates interest rate eisk from credit risk in ALCO pricing decisions. However, such a system does not guarantee that banks will be successful in isolating/manage the interest rate risk.

\section{Chapter 4}

\subsection{Funding Costs and banking risks.}

Interest rate risk. The above example demonstrate the difficulty of accurately projecting funding costs. Unanticipated changes in interest rates and in composition of bank liabilities can significantly affect net interest margin, depending on whether interest costs rise or fall faster than interest income. These changes also affect the bank risk position.

Today the majority of depositors and investors prefer short-term instruments that can be quickly rolled over as interest rates change. To induce investors to invest in the longer term and undertake more risk, banks must pay higher prices/yields. Many of the banks have decided not to increase prices in order to have long-term resources, but rely on frequent re-pricing of liabilities. The impact of this strategy on interest rate risk will depend on the measures taken by banks for re-pricing of assets with the same frequency. For this reason many attempt to price all loans on floating rate base and the duration of their investment portfolio no longer than 5 years.

To reduce interest rate risk and to maintain a lower cost of long-term funding the bank can compete for retail core deposits which are usually individual saving deposits.

Core deposits have a predictable cost, imply a degree of customer loyalty and are less interest rate-sensitive than alternative funding sources such as funds provided in the interbank market (money market liabilities). So, their interest expense is more stable when interest rates rise. In general, core deposit inflows will positively affect the bank's interest rate risk profile. Core deposits carry an additional advantage to banks because interest rates are lower, but they still cost more to handle.

Liquidity risk. Many depositors compare interest rates between available investment alternatives and move their funds toward alternative that provides the highest return/yields. For this reason it is getting more difficult to establish a stable and long term relationship with them, that withstand rate differentials. Large depositors react immediately to financial distress or even rumors, by shifting their funds into less risky instruments until the crisis passes.

Liquidity risk faced by banks depends on the competitive environment. Many banks operate in small communities where there is little competition. Clients want to invest their money locally (closer to home) so that they can conveniently contact the bank when they have questions or easily withdraw amounts of money. Liquidity risk is low and deposits outflows are predictable. Banks that operate in large communities usually face more aggressive competition, which increases liquidity risk. They should closely monitor the composition of their funds. It is important to note that the "core deposit" of the bank provide an advantage regarding liquidity.

Credit risk. Change in banks' funding costs indirectly affect the credit risk. This means that If "core deposit" is leaving the bank and the price it has to pay for new funding rises, the cost of funds will be higher. This can force the bank to lend more risky loans and consequently reduce the quality of assets. Due to the pressure of competition, it may not be 
able to re-price existing assets that have high quality to offset this increased costs. In these conditions, to maintain margins, banks lend riskier loans at higher promised yields. They may be able to maintain margin in the short term, but will increase losses over time from these loans as a result of their low quality. This effect is very sensitive to small banks that have limited opportunities to generate income from other activities.

Bank Safety. Now it is clear that funding costs and composition of funds are therefore central to many aspects of the Bank's earnings. The increase of funding cost reduce net interest margin. And if the bank does not have any other non-interest income or does not raise capital, the borrowing costs will rise even more and Bank suffer its safety in the aggregate.

\section{Conclusions}

Transfer Pricing System is a management accounting tool, which enables management to analyze profitability. At the same time, it assists management in pricing decision making. This technique allows managers to compare the profitability of different products, different branches and management and economic performance of the various units.

Like any other management tool, it should be used together with other techniques to offer to the management useful information on analysis and decision making process.

Type of transfer pricing system to be applied will depend on technological and human resources available, as well as approved objectives. Usage of a single transfer price, does not stimulate managers of specific profit centers when interest rates paid on deposits exceed the transfer price. On the other hand, users of funds are not encouraged when transfer price exceeds the interest rate paid on deposits. This situation does not support the process of asset/liability management. Providing an incentive for the growth of deposits should not increase the volume of loans, and the opposite.

Correlation of transfer price/cost of lending with cost of funds/return rate of interest earning assets makes it possible the flexibility in motivating the increase of deposits and loans independently to each other. For example, if the objective is to increase the deposit, transfer pricing for providers of funds will be placed higher than the return rate on interest earning assets.

\section{References}

Occasional Papers- Western Balcans in Transition - January 2004, European Commission

"Bank management", Timothy Koch, 1995 Edition

Funds transfer pricing: a management approach within the banking industry. Rice, Jennifer D.; Kocakulah, Mehmet C., July 2004.

"Managing the cost of funds", Thomas A. Farin

Transfer pricing for financial institutions, John Smullen, 2001 Edition 